\title{
The largest fossil rodent
}

\section{Andrés Rinderknecht ${ }^{1}$ and R. Ernesto Blanco ${ }^{2, *}$}

\author{
${ }^{1}$ Museo Nacional de Historia Natural y Antropología, Montevideo 11300, Uruguay \\ ${ }^{2}$ Facultad de Ingeniería, Instituto de Física, Fulio Herrera y Reissig 565, Montevideo 11300, Uruguay
}

\begin{abstract}
The discovery of an exceptionally well-preserved skull permits the description of the new South American fossil species of the rodent, fosephoartigasia monesi sp. nov. (family: Dinomyidae; Rodentia: Hystricognathi: Caviomorpha). This species with estimated body mass of nearly $1000 \mathrm{~kg}$ is the largest yet recorded. The skull sheds new light on the anatomy of the extinct giant rodents of the Dinomyidae, which are known mostly from isolated teeth and incomplete mandible remains. The fossil derives from San José Formation, Uruguay, usually assigned to the Pliocene-Pleistocene (4-2 Myr ago), and the proposed palaeoenvironment where this rodent lived was characterized as an estuarine or deltaic system with forest communities.
\end{abstract}

Keywords: giant rodents; Dinomyidae; megamammals

\section{INTRODUCTION}

The order Rodentia is the most abundant group of living mammals with nearly $40 \%$ of the total number of mammalian species recorded (McKenna \& Bell 1997; Wilson \& Reeder 2005). In general, rodents have body masses smaller than $1 \mathrm{~kg}$ with few exceptions. The largest living rodent, the carpincho or capybara (Hydrochoerus hydrochaeris), which lives in the Neotropical region of South America, has a body mass of approximately $60 \mathrm{~kg}$ (Mones \& Ojasti 1986). In South America lives also the pakarana (Dinomys branickii), a poorly studied sylvatic rodent that is the only living representative of the formerly highly diversified family Dinomyidae (see Fields 1957). The pakarana is also one of the largest living rodents, with a body mass of approximately $15 \mathrm{~kg}$ (White \& Alberico 1992). However, many fossil species of the Dinomyidae family reached a much larger body size. At present, approximately 50 fossil species of Dinomyidae are known, and Neoepiblemidae, another family of giant rodents, add 10 more species to South America's extinct fauna of large rodents (Mones 1986). Nevertheless, not much is known about the anatomy of these animals because the fossil remains are generally isolated teeth and small pieces of mandibles. Here we describe an exceptionally well-preserved, almost complete, skull of a new species of the family Dinomyidae, fosephoartigasia monesi.

We also estimate the body mass and discuss prior works related to giant fossil rodents.

- Mammalia Linnaeus 1758

- Rodentia Bowdich 1821

- Dinomyidae Alston 1876

- Fosephoartigasia (Francis \& Mones 1966) Mones 2007

- Fosephoartigasia monesi sp. nov.

\section{ETYMOLOGY}

Fosephoartigasia monesi dedicated to the palaeontologist Álvaro Mones for his studies on South American rodents.

*Author for correspondence (rinderk@adinet.com.uy).

\section{HOLOTYPE}

MNHN 921 (figures 1 and 2; Museo Nacional de Historia Natural y Antropología, Montevideo, Uruguay): almost complete skull without left zygomatic arch, right incisor, left M2 and right P4-M1.

\section{AGE AND LOCALITY}

Uruguay, Departament of San José, coast of Río de La Plata, 'Kiyú' beach $\left(34^{\circ} 44^{\prime} \mathrm{S}-56^{\circ} 50^{\prime} \mathrm{W}\right)$. The specimen was found in a boulder broken off from the San José Formation. It is composed of siltstone, claystones, medium-grained psammites and medium-to-conglomeratic psammites, with siltstone intercalations (Mones \& Rinderknecht 2004). Originally, it was assigned Pliocene age (Francis \& Mones 1965; Mones 1967), mainly based on several remains of mammals. However, recent studies have suggested the existence of Pleistocene levels in the formation (Mones 1988; McDonald \& Perea 2002). Giant bird remains from this unit, or attributed to it, have also been reported (Tambussi et al. 1999; Rinderknecht \& Noriega 2002).

\section{DIAGNOSIS}

Fosephoartigasia monesi is the largest recorded rodent. Like the only previously known species of the genus fosephoartigasia (Fosephoartigasia magna; Francis \& Mones 1966), the lophs are covered by a slightly undulated layer of enamel and separated by extremely thin sheets of cement. It is differentiated from $\mathcal{F}$. magna by its larger size and the almost equal occlusal surface area of all its molars. The relative length of the molar series is reduced and the incisors are proportionally mediolaterally wide (table 1).

\section{DESCRIPTION AND COMPARISON}

The skull has a total length of $53 \mathrm{~cm}$ (table 1; figure 1). The upper dentition is composed of two incisors, two premolars (P4) and six molars (M1-M3). The left root incisor (the only one preserved) is broad and heavy. The anterior face of this tooth is nearly flat and the enamel has tiny longitudinal striations. As in other Dinomyidae, the 


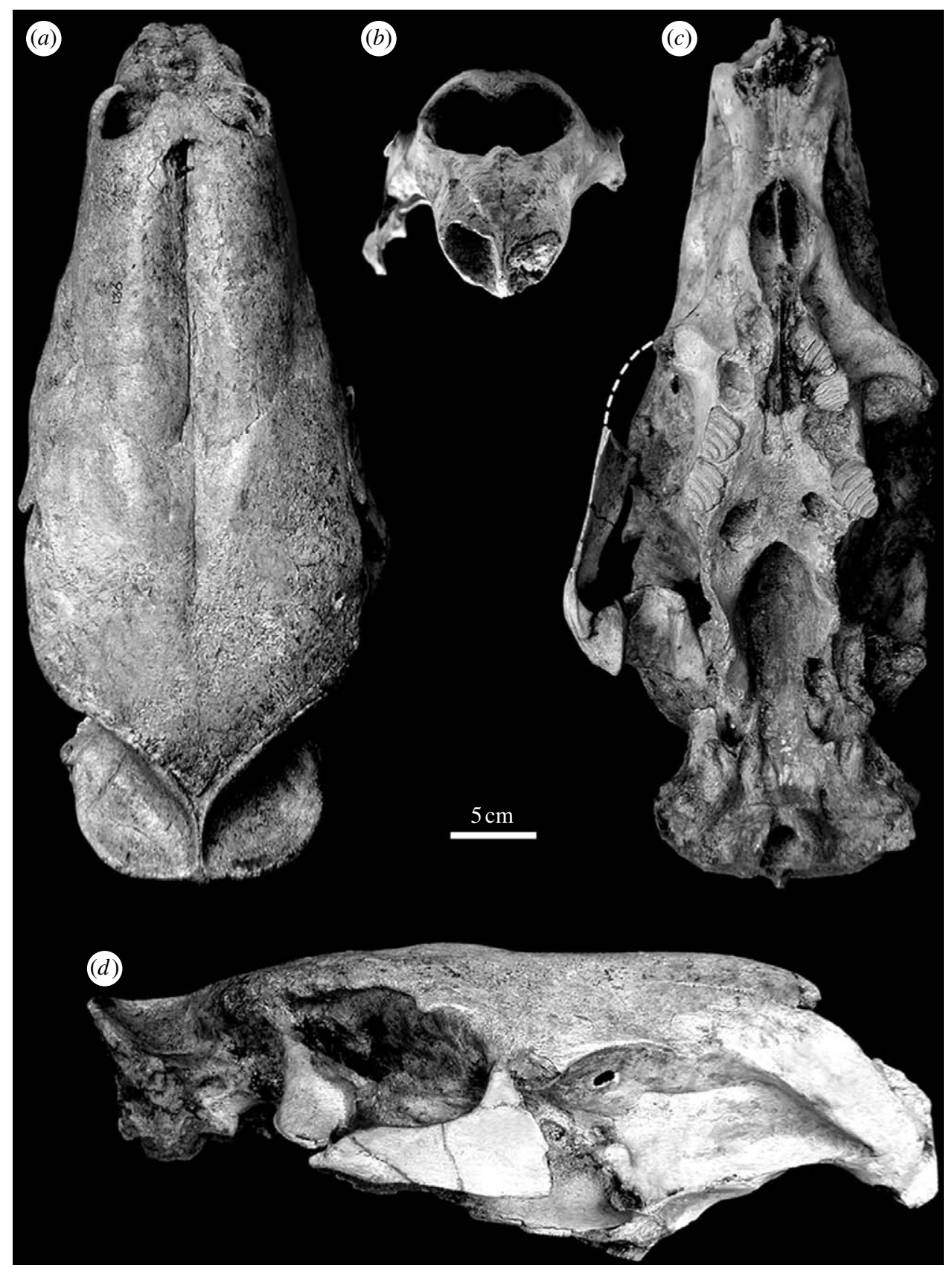

Figure 1. Skull of f. monesi sp. nov. (holotype, Museo Nacional de Historia Natural y Antropología MNHN 921) in (a) dorsal, (b) frontal, (c) ventral and $(d)$ lateral views.

premolars and molars have a series of transverse plates of dentine (lophs) covered by a thin film of enamel separated by a thin sheet of cement (figure 1). The extreme thinness of the cement filled and the slightly undulated shape of the enamel film are characteristic features of the genus fosephoartigasia (Francis \& Mones 1966; Mones 2007).

The P4, M1 and M2 are composed of five transverse plates; the two more anterior are isolated while the other three are fused on the lingual side. The M3 have six transverse plates with only the anterior three isolated.

The two series of grinding teeth converge strongly forward and are placed in an extreme anterior position. The last molar (M3) is located in a more anterior place than the orbit, a unique feature among rodents. Like other representatives of the Dinomyidae family (including the living species $D$. branickii), all grinding teeth are relatively small in comparison with skull size $\left(24 \mathrm{~cm}^{2}\right.$ in grinding area for each of the premolo-molar series).
The diastema is relatively short and has an incisive foramen of enormous size. The anterior region of the premaxillaries shows a thick tuberosity for muzzle muscle insertions, probably indicating the presence of a large muzzle.

Some skull bones, such as the nasals and frontals, are almost completely fused. In many cases this fusion is so complete that it is not possible to distinguish the shape and dimensions of some bones such as the lacrimals. The masseteric fossa for insertion of the masseter medial branch (=deep masseter) is the deepest among rodents and similar in shape to the one observed in Hydrochoerus. We cannot conclude, without further analysis, whether this feature is a result of heterochrony or an allometric effect.

Paradoxically, the zygomatic arches are very slender in comparison with other hystricognath rodents.

The frontals and the parietals are strongly fused forming a bulky bone complex and are difficult to distinguish from each other. This complex is laterally expanded (figure 2). 
Table 1. Anatomical measures used to obtain the allometrical equations (all lengths are in $\mathrm{mm}$ and body masses are in $\mathrm{kg}$ ). (Abbreviations are the same as given in figure legend 3.)

\begin{tabular}{|c|c|c|c|c|c|c|c|c|}
\hline & TL & DL & RL & BCL & $\mathrm{ZL}$ & IW & FW & $\begin{array}{l}\text { body } \\
\text { mass (kg) }\end{array}$ \\
\hline Hydrochoerus hydrochaeris MNHN 2589 & 176 & 45.7 & 118 & 42.2 & 90.1 & 18.7 & 63.1 & 19 \\
\hline Hydrochoerus hydrochaeris MHNH 2588 & 240 & 65.7 & 156 & 60 & 120 & 27.7 & 78.4 & 53.5 \\
\hline Hydrochoerus hydrochaeris MNHN 2558 & 265 & 73.6 & 170 & 57.5 & 124 & 30.1 & 82.7 & 73 \\
\hline Myocastor coypus $\mathrm{MNHN}$ w/n & 120 & 27.1 & 69.4 & 29.6 & 56.8 & 17.6 & 41.5 & 8 \\
\hline Ctenomys sp. MNHN 2307 & 44.6 & 14.9 & 26 & 13.3 & 20.2 & 7.3 & 11.9 & 0.146 \\
\hline Ctenomys sp. MNHN 2300 & 47 & 14 & 26.1 & 13.2 & 20.7 & 7.5 & 11.7 & 0.19 \\
\hline Ctenomys sp. MNHN 2309 & 42.1 & 12.1 & 23.7 & 11.6 & 19.6 & 6.5 & 11.6 & 0.158 \\
\hline Cuniculus paca $\mathrm{MNHN}$ w/n & 141 & 46.1 & 84.9 & 34.9 & 79.3 & 11.6 & 57.6 & 13 \\
\hline Cavia magna MNHN 2858 & 64.7 & 15.8 & 33.3 & 15.6 & 29.3 & 4.5 & 21.6 & 0.44 \\
\hline Cavia aperea MNHN 3222 & 64.8 & 17.8 & 36.1 & 16.1 & 28.6 & 4.8 & 19.8 & 0.583 \\
\hline Lagostomus maximus MNHN 3266 & 101 & 28.9 & 56.4 & 22.9 & 48.3 & 15.8 & 45.3 & 2.07 \\
\hline Coendou prehensilis MNHN 3954 & 101 & 28.5 & 51.2 & 29.8 & 42.8 & 9.9 & 35.2 & 4 \\
\hline Dinomys branickii MNHN 3796 & 161 & 36.2 & 75.8 & 39.3 & 65.9 & 21.3 & 52.8 & 12 \\
\hline fosephoartigasia monesi MNHN 921 & 530 & 149 & 289 & 128 & 214 & 67.3 & 191 & unknown \\
\hline
\end{tabular}

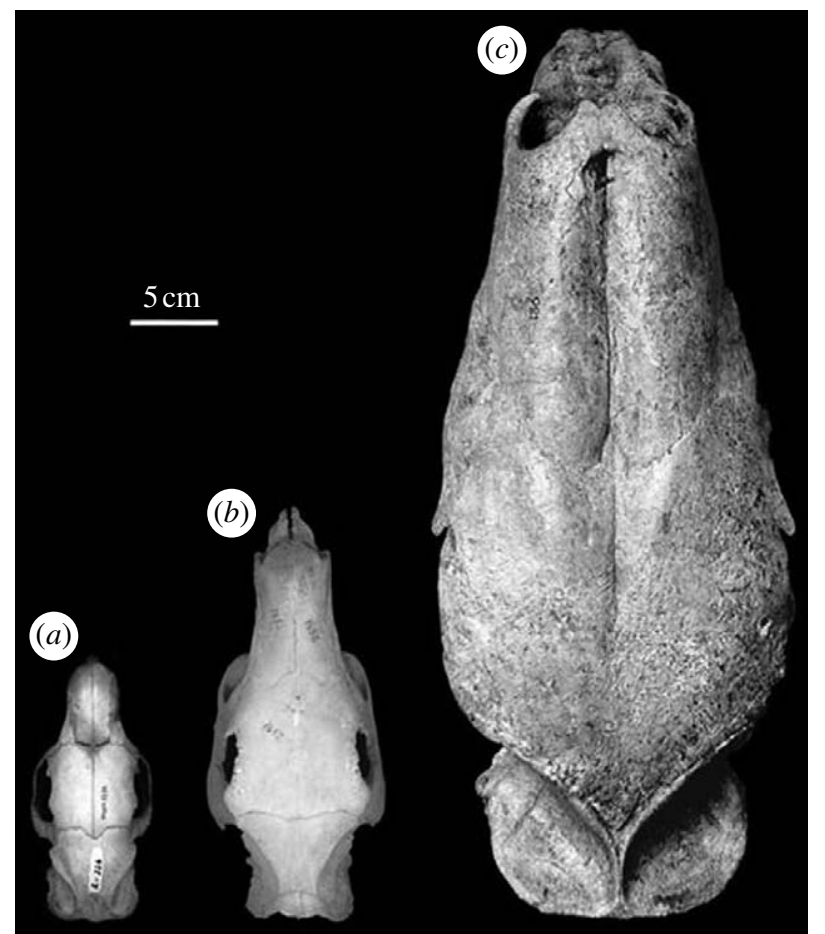

Figure 2. Skulls (dorsal view) of (a) D. branickii, (b) H. hydrochaeris and (c) F. monesi.

The temporal crests are exceptionally strong and converge rapidly to form a prominent and short sagittal crest. The temporal fossa is deep but narrow.

Owing to the extreme fusion of the skull bones, it is difficult to determine precisely the location of the orbitosphenoid bone and the optic foramen. The location of the optic foramen in other hystricognath rodents suggests that F. monesi should have an extremely reduced optic foramen in a region showing a very thin groove. The pterygoid fossa is observed in ventral view. This fossa is the insertion region of part of the pterygoid muscles and is relatively small in F. monesi. Like all the representatives of the subfamily Eumegamyinae, the foramen lacerum medium and the Eustachian canal are located in a deep pretympanic fossa.

The auditory bullae are small and much less globular than in other hystricognath rodents and the external auditory meatus is completely enclosed forming the meatal tube.

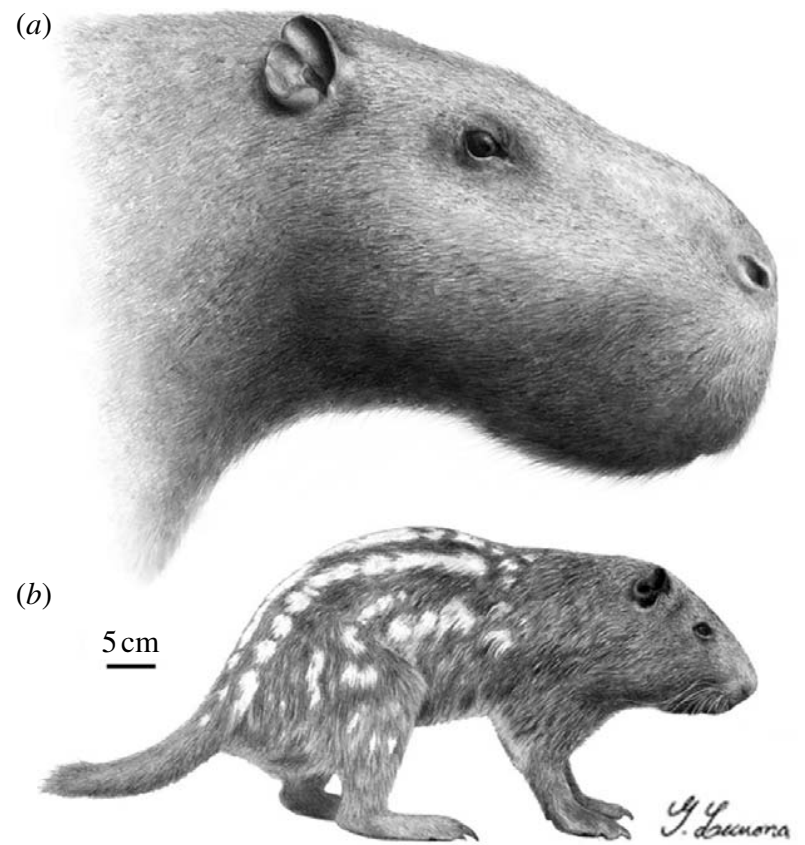

Figure 3. Reconstruction of the head of (a) F. monesi in comparison with (b) the living pakarana (D. branickii).

The occipital condyles generally have little relevance in phylogenetic analysis in mammals. However, these structures are diagnostic features of the Dinomyidae because the occipital condyles of these rodents (including the living species $D$. branickii) are unique in having paracondyles or accessory occipital condyles. The paracondyles are useful to distinguish the Dinomyidae from other families of giant rodents as the Neoepiblemidae, Hydrochoeridae and Heptaxodontinae (without paracondyles; Ameghino 1916; Frailey 1986; Mones 1997; Negri \& Ferigolo 1998). Fosephoartigasia monesi shows very developed paracondyles.

\section{PALAEOBIOLOGY AND CONCLUSIONS}

The dinomyids appear in South America in the Oligocene, but it was in the Miocene and the Pliocene that these rodents show a spectacular radiation, with many different species recorded in Argentina, Brazil, Uruguay, 

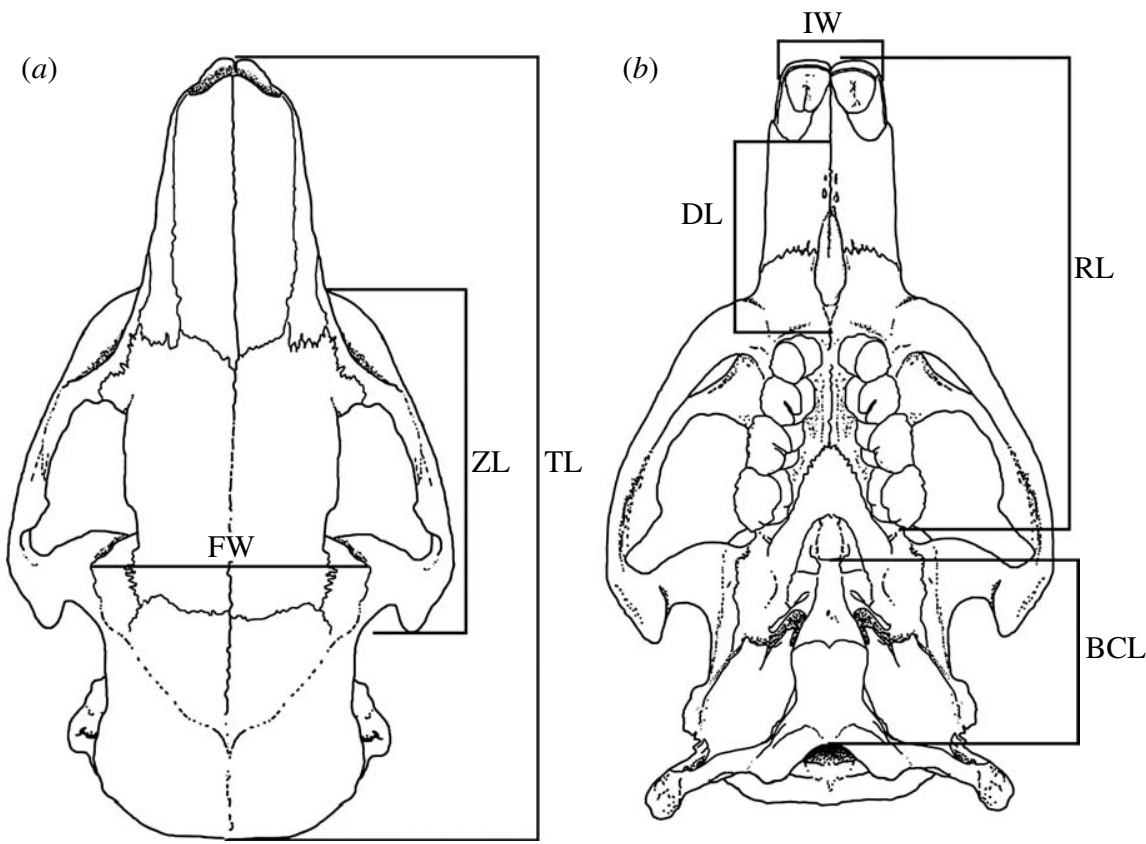

Figure 4. Skull of Myocastor coypus in (a) dorsal view and $(b)$ ventral view showing the skull variables used for allometric analysis. RL, rostral length; DL, diastema length; BCL, basicranial length (basioccipital + basisphenoid); IW, incisors width; ZL, zygomatic arch length; FW, frontal width; TL, total length.

Venezuela, Bolivia and Colombia (Mones 1986; White \& Alberico 1992). However, not much is known about these mammals because most of the fossils recovered are isolated teeth and incomplete mandibular remains. These kinds of fossils do not give much information about the palaeobiology, anatomy and phylogenetic relationship of the species. Nevertheless, the importance of this group is strongly supported by the great diversity of dental shapes and sizes, suggesting that dinomyids occupied many different ecological niches during the last 30 Myr in South America (Fields 1957).

The new complete skull offers important clues for palaeobiological inferences. It seems strange that with such a large and strong skull $\mathcal{F}$. monesi nevertheless had very slender zygomatic arches in comparison with other hystricognath rodents. In addition, the grinding teeth are very small and the pterygoid fossa is slightly reduced implying a minor lateral component to chewing. These features suggest that $\mathcal{F}$. monesi had weak masticatory muscles for grinding food and probably did not have the abrasive diet typical of other hystricognath rodents. Palaeobiologically this could imply a diet composed of soft vegetation and perhaps fruit. A reliance on aquatic plants would appear entirely congruent with the inferred palaeoenvironment and also the relatively small size of the teeth.

The proposed palaeoenvironment for $\mathcal{F}$. monesi is an estuarine or deltaic system with forest communities. The possible associated fauna include other giant rodents, sabre-toothed cats, giant carnivorous birds, xenarthrans, capybaras and assorted ungulates (McDonald \& Perea 2002; Rinderknecht \& Noriega 2002; Mones \& Rinderknecht 2004; Rinderknecht 2006).

The surprisingly large body size of this species suggests a particular palaeobiology for a rodent (figures 2 and 3). Body mass estimations based on predictive equations from data on living rodents are not very reliable due to the large body mass gap between the largest living rodent (capybara) and the much larger giant extinct rodent (figure 2; see Biknevicius et al. 1993; McFarlane et al. 1998). However, it is interesting to obtain some body mass estimation due to the ecological and life-history implications of size (Peters 1983). In any case, the skull described here is clearly larger than the poorly preserved skull of Phoberomys (family Neoepiblemidae) reported previously as the largest rodent that ever existed with a body mass estimated using postcranial measures (Sánchez-Villagra et al. 2003). The best comparison of size would be obtained by applying the same methods in both cases; but this cannot be done at present since we have no postcranial bones of fosephoartigasia.

In Reynolds (2002), the body mass of the giant extinct rodent Castoroides was estimated based on skull length, obtaining a maximum value of $200 \mathrm{~kg}$. If we apply the same method (with the same allometric relation) to f. monesi, we obtain a mean body mass of $1400 \mathrm{~kg}$ with a standard deviation of $533 \mathrm{~kg}$ and extreme values of 716 and $2250 \mathrm{~kg}$.

However, the sample of living rodents used to estimate Castoroides body mass is very broad, including many groups not closely related with dinomyids. We have obtained a new allometric relation between skull length and body mass using 13 specimens of eight genera of hystricognath rodents, the closest living relatives of fosephoartigasia (see table 1).

According to this allometric relation, the mass of Fosephoartigasia was $1008 \mathrm{~kg}$. Because the skull is almost complete, it is possible to check this estimate using other cranial measures. We have obtained allometric relations between body mass and six other standard cranial measures (Vassallo 2000) for the same sample of hystricognath rodents, and estimated the mass of fosephoartigasia using each of these (figure 4 ). The equations listed in table 2 were 
Table 2. Parameters ( $a$ and $b$ ) of the allometrical equations obtained to estimate body mass. (The general mathematical form is $M=a X^{b}$, where $M$ is the body mass $(\mathrm{kg})$ and $X$ is one of the anatomical measurements $(\mathrm{cm})$; abbreviations are the same as given in figure legend 4.)

\begin{tabular}{lll}
\hline$X$ & $a$ & $b$ \\
\hline $\mathrm{DL}$ & $1.031 \times 10^{-5}$ & $3.771 \pm 0.065$ \\
$\mathrm{FW}$ & $5.222 \times 10^{-5}$ & $3.118 \pm 0.066$ \\
$\mathrm{IW}$ & $1.919 \times 10^{-4}$ & $3.900 \pm 0.161$ \\
$\mathrm{ZL}$ & $6.635 \times 10^{-6}$ & $3.368 \pm 0.042$ \\
$\mathrm{BCL}$ & $9.104 \times 10^{-6}$ & $3.902 \pm 0.037$ \\
$\mathrm{RL}$ & $4.156 \times 10^{-6}$ & $3.316 \pm 0.051$ \\
$\mathrm{TL}$ & $2.297 \times 10^{-7}$ & $3.539 \pm 0.033$ \\
\hline
\end{tabular}

obtained by us from log-log linear regression by minimum squares. All the exponents are between 3.9 and 3.1. We estimated the body mass for the extinct rodent averaging the estimations for each cranial measure. A standard error and a maximum range of variation were also obtained by this method.

The average of all seven body mass estimates gives $1211 \mathrm{~kg}$ with a standard deviation of $753 \mathrm{~kg}$, when each of the estimates is given equal weight. The largest and smallest estimates of the mass of $\mathcal{F}$. monesi obtained are $2586 \mathrm{~kg}$ (from the extremely large width of the incisors) and $468 \mathrm{~kg}$ (from the very small zygomatic arches), respectively. Our method gives results very close to the ones following Reynolds (2002).

Our results are clearly consistent with a body mass greater than $400 \mathrm{~kg}$ (estimated from forelimb bones data) and $700 \mathrm{~kg}$ (estimated from hind limb bones data) of Phoberomys (Sánchez-Villagra et al. 2003). Moreover, the fragments available for the cranium of Phoberomys (Horovitz et al. 2006) indicate a skull of approximately $65 \%$ the size of that of Fosephoartigasia. We can thus conclude with a high degree of confidence that our specimen of $\mathcal{F}$. mones $i$ had a body mass about twice that of Phoberomys, making it the largest rodent known to have existed.

Our result reinforces the conclusions of a previous work (Sánchez-Villagra 2003), indicating that Rodentia displays the second largest range of sizes among mammalian orders, after diprotodontian marsupials.

We thank M. Reisenberger, E. Bostelmann, P. Mora and W. Jones for their comments. The drawings were made by G. Lecuona and the type material was collected by S. Viera.

\section{REFERENCES}

Ameghino, C. 1916 Algunas observaciones curiosas sobre una cabeza del género Tetrastylus de Catamarca. Physis 2, 429-430.

Biknevicius, A. R., McFarlane, D. A. \& MacPhee, R. D. E. 1993 Body size in Amblyrhiza inundata (Rodentia: Caviomorpha), an extinct megafaunal rodent from the Anguilla Bank, West Indies: estimates and implications. Am. Mus. Novit. 3079, 1-25.

Fields, W. R. 1957 Hystricomorph rodents from the Late Miocene of Colombia, South America. Univ. Calif. Publ. Geol. Sci. 32, 273-404.
Frailey, C. D. 1986 Late Miocene and Holocene mammals, exclusive of the Notoungulata, of the Río Acre Region, Western Amazonia. Contrib. Sci. 374, 1-46.

Francis, J. C. \& Mones, A. 1965 Sobre el hallazgo de Cardiatherium talicei $\mathrm{n}$. sp. (Rodentia, Hydrochoeridae) en la Playa Kiyú, Departamento de San José, República Oriental del Uruguay. Kraglieviana 1, 1-44.

Francis, J. C. \& Mones, A. 1966 Artigasia magna n. g., n. sp. (Eumegamyinae), un roedor gigantesco de la época Pliocena Superior de las Barrancas de San Gregorio, Departamento de San José, República Oriental del Uruguay. Kraglieviana 3, 89-100.

Horovitz, I., Sánchez-Villagra, M. R., Martin, T. \& Aguilera, O. A. 2006 The fossil record of Phoberomys pattersoni Mones, 1980 (Mammalia, Rodentia) from Urumaco (Late Miocene, Venezuela), with an analysis of its phylogenetic relationships. F. Syst. Paleontol. 4, 293-306. (doi:10.1017/S1477201906001908)

McDonald, H. G. \& Perea, D. 2002 The large scelidothere Catonix Tarijensis (Xenarthra, Mylodontidae) from the Pleistocene of Uruguay. F. Vertebr. Paleontol. 22, 677-683. (doi:10.1671/0272-4634(2002)022[0677:TLSCTX]2.0. $\mathrm{CO} ; 2)$

McFarlane, D. A., MacPhee, R. D. E. \& Ford, D. F. 1998 Body size variability and a Sangamonian extinction model for Amblyrhiza, a West Indian megafaunal rodent. Q. Res. 50, 80-89. (doi:10.1006/qres.1998.1977)

McKenna, M. C. \& Bell, S. K. 1997 Classification of mammals above the species level. New York, NY: Columbia University Press.

Mones, A. 1967 Notas paleontológicas uruguayas. I. Trigodon Amegh., 1882 (Toxodonta, Notoungulata) en la fauna pliocena superior de las Barrancas de San Gregorio, Dpto. de San José, Uruguay. Com. Zool. Mus. Hist. Nat. Montevideo 117, 1-4.

Mones, A. 1986 Palaeovertebrata Sudamericana. Catálogo Sistemático de los Vertebrados Fósiles de América del Sur. Parte I. Lista preliminar y bibliografía. Courier Forschungsinstitut Senckenberg 82, 1-625.

Mones, A. 1988 Notas paleontológicas uruguayas. IV. Nuevos registros de mamíferos fósiles de la Formación San José (Plioceno-Plesitoceno inferior?) (Mammalia: Xenarthra; Artiodactyla; Rodentia). Comun. Paleontol. Mus. Hist. Nat. Montevideo 20, 255-277.

Mones, A. 1997 Estudios sobre la familia Dinomyidae, II. Aportes para una osteología comparada de Dinomys branickii Peters, 1873 (Mammalia: Rodentia). Comun. Paleontol. Mus. Hist. Nat. Montevideo 29, 1-40.

Mones, A. 2007 Fosephoartigasia, Nuevo nombre para Artigasia Francis \& Mones, 1966 (Rodentia, Dinomyidae), non Artigasia Christie, 1934 (Nematoda, Thelastomatidae). Comun. Paleontol. Mus. Hist. Nat. Montevideo 36, 213-214.

Mones, A. \& Ojasti, J. 1986 Hydrochoerus hydrochaeris. Mammal. Species 264, 1-7. (doi:10.2307/3503784)

Mones, A. \& Rinderknecht, A. 2004 The first South American Homotheriini. Comun. Paleontol. Mus. Hist. Nat. Montevideo 35, 201-212.

Negri, F. R. \& Ferigolo, J. 1998 Anatomia craniana de Neoepiblema ambrosettianus (Ameghino, 1889; Rodentia, Caviomorpha, Neoepiblemidae) do Mioceno superiorPlioceno, Estado do Acre, Brasil, e revisão das species do gênero. Bol. Mus. Paraense Emílio Goeldi 10, 1-80.

Peters, R. H. 1983 The ecological implications of body size. Cambridge, UK: Cambridge University Press.

Reynolds, P. S. 2002 How big is a giant? The importance of method in estimating body size of extinct mammals. 7. Mammal. 83, 321-332. (doi:10.1644/1545-1542(2002) $083<0321$ :HBIAGT $>2.0$. CO;2) 
Rinderknecht, A. 2006 Vertebrados Fósiles de la Costa Uruguaya. Montevideo, Uruguay: Vida Silvestre.

Rinderknecht, A. \& Noriega, J. I. 2002 Un nuevo género de Anhingidae (Aves: Pelecaniformes) del Plioceno-Pleistoceno del Uruguay (Formación San José). Ameghiniana 39, 183-191.

Sánchez-Villagra, M. R., Aguilera, O. \& Horovitz, I. 2003 The anatomy of the world's largest extinct rodent. Science 301, 1708-1710. (doi:10.1126/science.1089332)

Tambussi, C., Ubilla, M. \& Perea, D. 1999 The youngest large carnassial bird (Phorusrhacidae, Phorusrhacinae) from South America (Pliocene-Early Pleistocene of Uruguay). F. Vertebr. Paleontol. 19, 404-406.

Vassallo, A. I. 2000 Alometría e isometría en varias especies de roedores caviomorfos, con comentarios sobre la estructura del aparato masticatorio del orden Rodentia. Mastozool. Neotrop. 7, 37-46.

White, T. G. \& Alberico, M. S. 1992 Dinomys branickii. Mammal. Species 410, 1-5. (doi:10.2307/3504284)

Wilson, E. D. \& Reeder, D. M. 2005 Mammal species of the world. A taxonomic and geographic reference, 3rd edn. Baltimore, MD: Johns Hopkins University Press. 